\title{
PARADOKS GANDA KOS PRODUKSI PETANI TEMBAKAU (STUDI FENOMENOLOGI PADA PETANI TEMBAKAU DI KABUPATEN JEMBER)
}

\author{
Whedy Prasetyo \\ Fakultas Ekonomi dan Bisnis, Universitas Jember \\ whedy.p@gmail.com
}

\begin{abstract}
This study focuses on the dual paradox of production cost phenomenon as a consequence of the tobacco market characteristics. More specifically, we motivate our study by emphasizing the oligopsonic price transaction and farmers' lack of direct access to factories. The paradox causes production costs to be determined by mediating actors between farmers and tobaccos. More specifically, tengkulak (middlemen) powerfully mediate business transactions between farmers and factories so that price fluctuation harms farmers. Using the phenomenology study, this research harmonizes the production costs determination from the planting time to harvesting time. The production cost harmonization shows that farmers and factories initiate intensive and open communication about their own production costs. It is therefore expected that this practice could eliminate the oligopsonic market and the one-sided price determination by tengkulak who mainly act for cigarette industry. Eventually, it is also expected that the dual paradox of production cost determination could be eliminated.
\end{abstract}

Keywords: dual paradox of production cost, farmer, tengkulak and oligopsony.

\begin{abstract}
ABSTRAK
Fenomena paradoks ganda kos produksi akibat pasar tembakau merupakan kajian penelitian ini. Kajian ini merujuk akibat transaksi harga yang bersifat oligopsoni dan petani tidak memiliki akses langsung ke pabrik. Paradoks seperti ini membuat kondisi antara petani dan pabrik menentukan beban produksi. Beban produksi yang terjadi akibat proses jual-beli diperantarai oleh tengkulak, sehingga fluktuasi harga tembakau merugikan petani. Penelitian ini mengunakan studi fenomena. Hasil penelitian mewujudkan harmonisasi penentuan kos produksi dari awal masa tanam sampai panen. Harmonisasi kos produksi seperti ini menunjukkan pabrik dan petani membuka wahana komunikasi intensif dan terbuka beban produksi yang harus dikeluarkan masing-masing. Hasil ini diharapkan mengakhir fenomena oligopsoni dan penetapan harga tembakau secara sepihak oleh tengkulak yang menjadi kaki tangan industri rokok. Oleh karena itu, sudah waktunya cerita paradoks ganda penentuan kos produksi diakhiri.
\end{abstract}

Kata kunci: paradoks ganda kos produksi, petani, tengkulak dan oligopsoni. 


\section{PENDAHULUAN}

Rencana Strategis Kementerian Pertanian tahun 2010-2014 menyatakan bahwa komoditas tembakau merupakan salah satu dari 39 produk unggulan nasional. Tembakau merupakan produk unggulan perkebunan non pangan yang menempatkan Indonesia dalam peringkat ke-7 sebagai negara produsen tembakau. Selama ini pertambahan produksi perkebunan tembakau berkisar 3,75 persen dalam 4 tahun, sehingga salah satu target dari rencana strategis ini adalah meningkatkan produksi tembakau menjadi 184 ribu ton dengan produktivitas 893 kilo per hektar pada tahun 2014.

Peningkatan produksi tembakau tersebut digunakan untuk prioritas tujuan penerimaan devisa (ekspor), pemenuhan kebutuhan bahan baku industri dalam negeri dan substitusi impor. Kondisi ini membuat upaya perlindungan dan pemberdayaan petani sangat diperhatikan oleh pemerintah. Sebagaimana penetapan UndangUndang Nomor 19 Tahun 2013 tentang Perlindungan dan Pemberdayaan Petani. Perlindungan petani adalah segala upaya untuk membantu petani dalam menghadapi permasalahan kesulitan memperoleh prasarana dan sarana produksi, kepastian usaha, risiko harga, kegagalan panen, dan perubahan iklim. Selanjutnya, pemberdayaan petani adalah segala upaya untuk meningkatkan kemampuan petani untuk melaksanakan usaha tani yang lebih baik melalui pendidikan dan pelatihan, penyuluhan dan pendampingan, konsolidasi dan jaminan luasan lahan pertanian, teknologi dan informasi serta penguatan kelembagaan petani.

Perlindungan dan pemberdayaan tersebut bertujuan untuk mengembangkan varietas dan varian produk tembakau. Pengembangan ini diharapkan mampu mempertahankan tanaman tembakau sebagai komoditas ekspor andalan Indonesia, dan mampu memberikan pendapatan kepada pelakunya (IISD 2015). Karena itu, untuk mencapai pengembangan tersebut dukungan perhatian diberikan oleh pemerintahan bagi industri tembakau dari hulu sampai hilir. Perhatian ini merupakan usaha untuk melakukan penyelamatan penerimaan negara dan penyerapan tenaga kerja yang besar.

Aspek teknis pertanian seperti penjelasan di atas menunjukkan tembakau adalah tanaman pertanian yang ditanam, dipelihara dan dipanen lalu dijual oleh petani sebagai salah satu komoditas pertanian yang menguntungkan. Namun, tembakau menjadi pelik ketika dihubungkan dengan produk olahannya yaitu rokok. Industri rokok Indonesia memiliki kekhasan dan keunikan tersendiri dan telah diakui dunia atau telah menjadi bagian dari warisan budaya kita (national heritage). Hal ini yang membuat pro-kontra rokok dengan segala atribut sosial, ekonomi, dan kulturalnya serta terutama persoalan dampak kesehatan dan moralitas. Pro-kontra ini berujung pada dua aspek, yaitu ekonomi dan kesehatan.

Aspek ekonomi menjadi fokus kajian telaah penelitian ini, sebagaimana dilangsir dari beritasatu.com bahwa untuk tahun 2013 permintaan produk tembakau 
dalam bentuk rokok dan cerutu mencapai 302 miliar batang dalam setahun. Jumlah ini diprediksi meningkat sebesar 61,4 persen per tahunnya, artinya pasar tembakau sangat terbuka lebar untuk para petani tembakau (Rachmad 2015). Penjelasan ini sejalan dengan (IISD 2015) yang menyatakan bahwa konsumsi rokok dan cerutu telah meningkat 12 kali dalam kurun waktu 44 tahun. Kedua penjelasan menunjukkan angka pertumbuhan yang menakjubkan, karena telah mampu melewati angka yang ditargetkan oleh Road Map Industri Produk Tembakau.

Road Map tersebut menargetkan produksi sebesar 220 milyar batang rokok pada kurun waktu 2006 sampai 2010, 240 milyar batang pada kurun 2010 sampai 2015, dan 260 milyar batang pada kurun 2015 sampai 2016. Jumlah angka konsumsi produk tembakau di Indonesia ini cenderung meningkat dan terus berlanjut. Di samping itu industri tembakau nasional menyerap tenaga kerja cukup signifikan. Saat ini, sebanyak 4,15 juta pekerja bekerja di industri tembakau, dimana 93,77 persen diserap kegiatan usaha tani termasuk pasca panen dan 6,23 persen di sektor pengolahan rokok. Begitu juga cukai dari produksi rokok masih menjadi andalan karena memberikan kontribusi sebanyak 96 persen dari total penerimaan cukai negara. Di samping itu, jumlah petani tembakau saat ini sekitar 689.360 orang, dengan total luas areal pada kisaran 221 ribu hektar yang tersebar di lima belas propinsi. Jenis produk tembakau yang dihasilkan selain bentuk rokok dan sejenisnya (cerutu, shag atau rokok tingwe/gulung sendiri), juga dapat digunakan menjadi bahan kimia dasar sebagai pestisida, obat bius, produk kosmetik, industri farmasi. Indonesia berada pada posisi kelima negara penghasil tembakau di dunia dengan total 1,91 persen atau sebesar 135 ribu ton dari 7,1 juta ton produksi dunia (TCSC-Indonesia 2012; SEATCA 2008). Namun untuk periode selanjutnya, karena mempertimbangkan aspek ekonomi maka angka produksi sebesar 260 milyar batang dan pertumbuhan industri rokok akan dipertahankan.

Pesatnya pertumbuhan produksi dan konsumsi rokok serta keuntungan berlipat yang dinikmati industri rokok tersebut tidak serta-merta diikuti peningkatan kesejahteraan petani. Padahal petani tembakau adalah ujung tombak dalam tata niaga pertembakauan. Merujuk pada data yang dikeluarkan oleh Badan Pusat Statistik (BPS) melangsir bahwa penghasilan petani tembakau di Indonesia pada tahun 2015 masih berada di bawah Upah Minimum Regional (UMR) (Rachmad 2015). Data ini sudah cukup menggambarkan betapa petani tembakau merupakan kelompok paling rentan, dan mempunyai posisi tawar rendah dalam mata rantai tata niaga tembakau. Mengapa demikian? Pertama, tanaman tembakau adalah tanaman semusim yang hanya dapat tumbuh di musim kemarau.

Kedua, pasar tembakau adalah bersifat oligopsoni, artinya mekanisme penentuan harga ditentukan oleh industri. Di samping kedua aspek ini juga akibat fluktuasi harga besar dan cenderung tidak menentu. Kondisi ini menyebabkan petani menghadapi berbagai permasalahan dari hulu ke hilir pada penentuan kos produksi yang tinggi atas biaya penanaman dan padat modal, risiko kesehatan akibat proses 
penanaman tembakau dan timpangnya tata niaga yang meniadakan standar harga dan kepastian usaha, serta perubahan iklim dan anomali cuaca. Hal ini mengakibatkan risiko kerugian.

Selanjutnya, aspek kebijakan pemerintah (dalam hal ini Kementerian Pertanian (Kementan) dan Kementerian Perdagangan (Kemendag)), yaitu ketika Kementan berupaya meningkatkan kualitas dan produksi pertanian tembakau. Kemendag ini berwenang pada urusan ekspor-impor justru tidak melakukan pembatasan impor tembakau. Permintaan produk tembakau yang terus meningkat kemudian ditutup oleh impor. Hasilnya, permintaan tinggi tidak berkorelasi positif dengan nasib petani tembakau. Mereka tidak menikmati keuntungan yang maksimal dari situasi tersebut.

Mekanisme pasar di atas merupakan penjelasan nyata kondisi petani tembakau yang menghadapi paradoks ganda kos produksi (dual paradox of production cost). Di satu sisi, industri tembakau menikmati keuntungan melimpah akibat konsumsi rokok yang terus meningkat, namun di sisi lain kehidupan petani tembakau yang memberikan kontribusi besar bagi pertumbuhan industri tembakau justru tidak menikmati keuntungan sebanding. Penelitian ini berupaya memberikan bukti dan penjelasan tentang paradoks ganda kos produksi tersebut, sehingga dapat memberikan solusi yang mampu memperbaiki kehidupan petani tembakau di Jember. Hal ini menjadi titik perhatian penelitian ini karena tanaman tembakau menjadi ikon dan tanaman produksi yang terus dikembangkan serta sekaligus untuk mendukung misi sebagai komoditi unggulan di Kabupaten Jember.

\section{KAJIAN PUSTAKA DAN PERUMUSAN HIPOTESIS}

Petani sebagai mata rantai awal sekaligus produsen, dianggap tidak memiliki posisi tawar. Keresahan petani terletak pada penentuan harga jual produksi (Rachmad 2015). Kos produksi merupakan kos yang diperlukan untuk memperoleh bahan baku (mentah) dan mengubahnya menjadi produk selesai yang siap jual (Sugiri 2009) . Penjelasan ini memberikan pengertian bahwa kos produksi adalah kos yang dikeluarkan perusahaan untuk menghasilkan produk. Hal ini seperti ditegaskan pula oleh Suwardjono (2016); Samryn (2013) serta The dan Sugiono (2015) bahwa kos produksi terpusat pada perolehan bahan baku sampai produk terjual.

Penjelasan kos produksi tersebut menunjukkan bahwa perusahaan yang menentukan kos produksi tersebut. Namun, kos produksi untuk tanaman tembakau petani juga menentukan. Mengapa demikian? Pertanian tembakau memiliki sejumlah risiko yang mempengaruhi kos produksi, antara lain risiko perubahan cuaca, risiko perubahan harga, risiko hama tanaman dan risiko hilangnya permintaan.

Risiko perubahan cuaca dan harga tersebut merujuk pada Saliem (2014) dan Chamim (2011) yang menjelaskan bahwa tembakau adalah tanaman sangat sensitif 
terhadap hujan. Walaupun tanaman tembakau sudah siap panen, namun jika terjadi hujan beberapa hari sebelum panen, maka hal ini akan mengakibatkan turunnya kualitas dan harga daun tembakau. Di sisi lain, jika tidak ada hujan sama sekali, maka tanaman tembakau akan sulit berkembang. Sudah menjadi tradisi turuntemurun apabila memasuki bulan Mei atau sudah akhir dari musim penghujan sudah memulai menanam tembakau. Penjelasan ini merujuk dari penjelasan Jayadi dan Arbiansyah (2012) sebagai berikut:

\begin{abstract}
"Kondisi iklim penghujan merupakan faktor kegagalan panen tembakau. Iklim ini tidak sesuai dengan kondisi tanaman tembakau yang hanya membutuhkan air dalam jumlah sedang. Oleh karena itu, petani tembakau menyiapkan tempayang (galian menampung air) sebagai bentuk kebutuhan air tidak banyak. Sehingga bulan mei menjadi masa tanam dan panen jatuh pada Agustus sampai Oktober dengan harapan hasil tembakau mendapatkan cukup cahaya matahari untuk pengeringan."
\end{abstract}

Faktor cuaca tersebut menjadi risiko produksi berhasil tidaknya tembakau. Hal ini sebagaimana pula dinyatakan IISD (2015) bahwa gagal panen dan gagal produksi sering terjadi karena faktor cuaca yang tidak menentu dan tidak bisa diprediksi, khususnya sejak 2007 hingga sekarang. Selanjutnya risiko perubahan harga terjadi karena tidak adanya sistem baku dalam penetapan harga tembakau. Penetapan harga ini ditentukan secara subjektif oleh tengkulak berdasarkan warna dan aroma. Penjelasan ini sejalan dengan pernyataan Mastur (2014) sebagai berikut:

"Hujan sangat tidak diharapkan pada minggu-minggu terakhir masa panen. Sekali saja hujan lebat di minggu akhir sebelum masa petik dapat menggagalkan seluruh panen. Tembakau yang terkena hujan menjadi berbintik-bintik, mengandung banyak nikotin, aroma berkurang dan hampir tidak ada tengkulak yang menghendakinya."

Warna dan aroma itu menunjukkan tembakau yang berkualitas dan bebas dari hama. Risiko hama tanaman dan hilangnya permintaan ini merupakan tantangan bagi petani untuk menjaga proses tanam sampai siap panen. Sebagaimana hal ini dijelaskan oleh Jayadi dan Arbiansyah (2012) serta IISD (2015) bahwa perawatan tanaman tembakau memerlukan ketelatenan, karena banyaknya tahapan dalam proses penanamannya. Ada sembilan tahapan dalam proses penanaman tembakau, yaitu persiapan lahan, pengolahan lahan, pembuatan guludan, pemindahan bibit, penanaman, pemeliharaan tanaman, pemangkasan, pemetikan dan pengolahan hasil. Di dalam semua tahapan itu terdapat risiko tanaman tembakau terkena hama tanaman. Selanjutnya, risiko hilangnya permintaan terjadi pada saat petani memanen hasilnya, namun pabrik tidak bersedia untuk membelinya, karena masih banyaknya persediaan.

Petani selain menghadapi risiko di atas juga kondisi pasar tanaman tembakau yang bersifat oligopsoni. Pasar ini menurunkan posisi tawar petani. Petani tidak memiliki akses langsung ke pabrik. Proses jual-beli produk tembakau diperantarai middlemen atau tengkulak. Kemudian tengkulak ini menjualnya kembali kepada pedagang (pengepul) sedang hingga di jual kembali kepada pengepul besar yang ditunjuk oleh pabrik (up coper). Merujuk kepada hasil penelitian Rokhmah (2014) 
dan Santoso (2011) menyatakan bahwa prediksi harga yang ditulis tengkulak menjadi patokan awal harga dan dikemas ke dalam keranjang tanpa uang muka. Setelah itu, hasil tembakau ditampung oleh pedagang besar untuk dikumpulkan dan disimpan beberapa saat sambil menunggu perwakilan pabrik rokok membuka gudangnya untuk pembelian pengadaan stok tembakau.

Senada dengan penjelasan hasil penelitian tersebut sebagaimana dijelaskan Tobacco Control Support Center (TCSC)-Indonesia (2012) bahwa pengadaan stok tembakau bagi pabrik rokok dilakukan setelah masa panen tiba dan umumnya membuka kuota pembelian dengan sangat terbatas. Mengapa demikian? Hal ini merupakan strategi untuk mendapatkan barang berkualitas baik, tetapi dengan harga yang sangat rendah. Sebagai ilustrasi penjelasan ini mendasarkan pada kajian studi kasus penelitian yang dilakukan IISD (2015) pada petani tembakau di TemanggungJawa Tengah adalah:

\begin{abstract}
"Harga tembakau ditentukan pedagang besar dengan harga Rp75.000,00. Harga ini dikalikan dengan jumlah kilogram tembakau yang dijual atau disetorkan. Karena pedagang ini mempunyai akses yang baik dengan pabrik dan hanya melalui dialah hasil tembakau bisa diterima oleh pabrik, rata-rata 20 sampai 30 persen per kilogram. Pedagang besar akan membayar kepada pedagang kecil atau belandang dengan harga Rp50.000,00 per kilogram, kemudian oleh tengkulak dengan berbagai alasan seperti pengembalian modal, transportasi, sewa gudang dan lain-lain, maka harga yang diterima petani berkisar antara Rp15.000 - Rp20.000 (sekitar 10-30 persen) dari harga jual sesungguhnya. “
\end{abstract}

Kondisi seperti itu mengakibatkan fluktuasi harga tembakau yang merugikan petani. Karena posisi tengkulak yang istimewa ini memberikan posisi tawar yang tinggi, dan mengendalikan "permainan" harga, serta potongan harga bisa mencapai 20 persen sampai 25 persen. Penjelasan ini merujuk pada Chamim (2011) sebagai berikut:

"Praktek penjualan kepada tengkulak membuat petani mengalami kerugian, karena bila petani menjual 1 kwintal maka pemotongan timbangan di tengkulak bisa mencapai 20-25 kilogram. Petani juga harus menanggung biaya produksi seperti membayar buruh tanam, buruh pengrajin tembakau, pupuk dan lain-lain. Biaya ini yang tidak pernah dirasakan oleh tengkulak. Seharusnya mendapatkan untung, tapi kok malah buntung!"

Senada dengan Chamim tersebut juga diungkapkan oleh TCSC-Indonesia (2012) adalah:

\footnotetext{
"Risiko harga yang dialami petani sangat dipengaruhi oleh tata niaga tembakau yang tidak langsung menjual produksi olahan tembakau kepada pabrik, tetapi harus melalui mata rantai perdagangan yang panjang dan penuh ketidakpastian dalam penentuan harga beli yang didasarkan pada penimbangan tembakau. Misalkan petani mengukur hasil panen seberat 1 kwintal tetapi pada sesampainya di tengkulak besarnya timbangan itu hanya 93 kilogram atau maksimal 96 kilogram saja."
}

Sistem potong timbangan tersebut merupakan mekanisme yang diterima petani sebagai pengganti biaya untuk transportasi dan komisi telah membantu meloloskan tembakau tersebut ke gudang (IISD 2015). Pembayaran di akhir 
pembelian lebih parah, selain menghadapi persoalan potongan timbangan tersebut, petani masih terancam tidak dilunasi jika tengkulak merugi. Hal ini merujuk pada penjelasan Jayadi dan Arbiansyah (2012) berikut ini:

"Berat satu bal tembakau adalah 51 kilogram, biasanya tengkulak menghitungnya 50 kilogram. Selain itu tengkulak masih akan memotong "kepala”, yaitu 5 kilogram, karena beratnya 50-an kilogram. Petani tidak berani melawan dan ini juga ditambah apabila tengkulak rugi tak mampu melunasi pembayaran. Atas kondisi ini petani memilih membiarkan dirinya kehilangan uang tembakau."

Lemahnya posisi petani di depan tengkulak diakibatkan oleh panjangnya rantai niaga tembakau. Petani tidak dapat menjual tembakau secara langsung kepada juragan, karena juragan hanya menerima pembelian dalam jumlah besar. Tengkulak adalah kepanjangan tangan juragan untuk membeli tembakau-tembakau dari petani. Setiap tembakau yang dibeli ini disesuaikan dengan kriteria tembakau yang dibutuhkan oleh pabrikan. Untuk itu, tengkulak melakukan pengelompokan jenis tembakau perjenis pabrik. Pabrikan telah memberikan arahan tentang kualitas yang akan dibelinya, misalnya soal keharuman, warna dan kelengketan tembakau (Santoso 2011; Rokhmah 2014; Rachmad 2015).

Posisi tengkulak yang sangat menentukan tersebut membuat petani menerima penetapan harga beli. Harga ini berbanding lurus dengan kriteria kualitas tembakau yang diinginkan tengkulak. Kualitas ini menurut IISD, (2015) adalah kualitas yang ditentukan pabrik tanpa standar yang tetap, namun didasarkan pada penilaian fluktuasi harga di daerah lain (atau bahkan tembakau impor), dan stigma campuran tembakau dengan tembakau lain serta cuaca maupun cara tanam yang kurang baik. Penentuan harga ini berbanding terbalik dengan kondisi petani dalam proses penanaman tembakau yang membutuhkan biaya besar. Merujuk hasil penelitian Keyser dan Juita (2005) menunjukkan bahwa pertanian tembakau membutuhkan biaya tanam besar hampir Rp15 juta perhektar (ha).

Jumlah biaya tersebut sebagaimana pula dinyatakan oleh Jayadi dan Arbiansyah (2012) bahwa penanaman tembakau membutuhkan biaya Rp13 juta sampai Rp16 juta per ha. Jumlah ini hampir sama dengan biaya tanam cabe dan kentang. Namun menanam cabe dan kentang ini memberikan penghasilan yang relatif sama dan lebih baik ketimbang tembakau dengan jumlah hari kerja yang jauh lebih sedikit. Kondisi ini membuat pengeluaran untuk biaya masa tanam sampai panen menjadi besar. Namun jumlah pengeluaran ini tidak sejalan dengan proses dalam pembelian tembakau oleh tengkulak. Petani hanya punya dua pilihan; terima atau tinggalkan. Kedua pilihan yang mayoritas menerima harga yang ditetapkan, walaupun di bawah kos produksi minimal atau Break Event Point (BEP).

\section{METODA PENELITIAN}


Fenomenologi menjadi instrumen dalam penelitian. Hal ini dalam rangka menghadirkan kondisi nyata petani tembakau yang menghadapi paradoks ganda kos produksi (dual paradox of production cost). Paradoks untuk menunjukkan di satu sisi, industri tembakau menetapkan kos produksi pada pembelian tembakau, selanjutnya di pihak petani juga menetapakan kos produksi sebagai perhitungan mulai masa tanam sampai panen. Oleh karena itu, kajian fenomena ini berupaya memberikan bukti dan penjelasan tentang paradoks ganda kos produksi tersebut, sehingga dapat memberikan solusi yang mampu memperbaiki kehidupan petani tembakau di Jember. Penelitian ini dilakukan dengan cara wawancara mendalam. Arah wawancara mendalam adalah proses pelaksanaan fenomenologi untuk mengungkapkan kondisi nyata obyek penelitian (Kuswarno, 2009; Basrowi dan Soenyono, 2004). Selain wawancara mendalam juga dilakukan pengamatan langsung mekanisme transaksi dalam penentuan beban produksi petani.

Petani tembakau yang diteliti sebanyak 4 orang yang berada di Desa Kesilir Kecamatan Wuluhan-Jember. Keempat petani ini pada saat dilakukan penelitian sedang melakukan panen, yaitu Husein, Ahmad, Kamri dan Ridho. Di samping petani, peneliti juga mengamati dialog yang dilakukan antara keempat petani tersebut dengan tengkulak (bandol) yang bernama Yayuk. Interaksi ini bertempat di rumah petani bernama Husein. Wawancara dilakukan terbuka selama lima bulan dari tanggal 1 April sampai 31 Agustus 2015. Wawancara terbuka bertujuan untuk mengungkapkan fenomena penentuan kos produksi pada transaksi perdagangan tembakau. Wawancara seperti ini menghadirkan suasana yang akrab dan jawabanjawaban spontan, hal inilah yang menjadi nilai "unik" dan sangat berharga bagi penelitian ini.

\section{ANALISIS DAN PEMBAHASAN}

Persoalan penetapan harga daun tembakau secara sepihak oleh tengkulak yang menjadi kaki tangan industri rokok menjadi sebuah fenomena yang dialami oleh petani tembakau. Fenomena ini membuat ketetapan penentuan harga menjadi miliknya, sehingga memberikan posisi tawar yang tinggi dan sebaliknya bagi petani. Di samping itu menumbuhkan ketergantungan sangat tinggi kepada tengkulak.

Posisi seperti itu membuat opsi penjualan tembakau menjadi dua yaitu, beli langsung dalam bentuk tanaman (tebbasan) dan rajangan. Harga tembakau tebbasan lebih murah daripada rajangan, karena tanpa melewati proses pemetikan, penggulungan, penyimpanan, perajangan, dan penjemuran. Hal ini didasarkan pada pernyataan Ahmad sebagai berikut:

"Secara produksi kauleh ngasteteh ngeluaragi biaya, karena panen kuduh menyesuaiagi kalaben argeh bandol. Melanah deri kakdintoh bekoh deddi duek pelean, yaitu langsung (tebbasan) ben rajangan. Kauleh lebbi mele tebbesen karena umummah ebeli delem etongan per saebuh po'on, misallah duek setengah limak juta. Beko rajangan lebbi larang, tape kadeng tak lebbi ngontongagi."[Secara produksi 
saya hati-hati mengeluarkan biaya, karena panen harus menyesuaikan dengan harga tengkulak. Oleh itu tembakau menjadi dua pilihan, yaitu langsung (tebbasan) dan rajangan. Saya lebih memilih tebbasan karena umumnya dibeli dalam hitungan perseribu pohon, misalnya dua setengah juta. Tembakau rajangan lebih mahal, namun kadang tidak lebih menguntungkan.]

Senada dengan Ahmad, Husein juga menyatakan:

\begin{abstract}
"Petani ngadebbih argeh bandol. Penetapan argeh kakdintoh aberri' ketidakpastian se saongkunah kauleh rassa'agi lebbi suka ajuel tebbesen. Namun jugen bedeh se ajuel rajangan, biasanah petani se andik modal, kaanggui majer kuli petik (se molong), se agulung, se arajang, ben se ajemur." [Petani menghadapi harga tengkulak. Penetapan harga ini memberikan ketidakpastian yang kalau saya rasakan lebih suka menjual tebbasan, namun juga ada yang menjual rajangan, biasanya petani yang memiliki modal untuk membayar kuli petik, gulung, rajang, dan jemur.]
\end{abstract}

Harga tengkulak sebagaimana dimaksud Ahmad dan Husein tersebut senada dengan pernyataan Saliem (2014) yang menyatakan bahwa tengkulak memberikan harga kepada petani tembakau berdasarkan informasi dari pabrik dan perhitungan sendiri. Informasi ini tidak sampai kepada petani, sehingga seringkali mengambil keuntungan dari proses jual beli tembakau dengan memainkan harga. Misalnya pabrik mematok harga tembakau di beli 25 ribu rupiah namun dari tengkulak hanya mau membayar 17 ribu lima ratus rupiah sampai 21 ribu rupiah saja. Belum lagi untuk mentolerir perbedaan kualitas tembakau, tengkulak melakukan pemotongan 8 persen sampai 10 persen dari jumlah timbangan petani.

Penentuan mutu tembakau ditentukan secara manual dan visual. Ukuran standar mutu tembakau meliputi warna, pegangan atau body, aroma, tingkat kekeringan, kebersihan, kemurnian, ketuaan daun, posisi daun dan lebar rajangan. Di samping kriteria tersebut, tembakau diklasifikasikan ke dalam beberapa jenis mutu yang menentukan harga masing-masing. Dari uraian ini tampak bahwa harga dan penilaian mutu tembakau didominasi oleh tengkulak.

Keterkaitan penentuan harga dengan mutu tembakau seperti itu bersifat fancy product, artinya harga ditentukan oleh mutu tembakau yang dihasilkan. Akibatnya, harga bisa berubah tergantung kepada tingkatan mutu tembakau yang dijual. Dalam posisi ini, tengkulak sebagai pihak yang menentukan harga tembakau berkuasa penuh untuk menetapkan mutu suatu tembakau masuk ke kualitas yang mana. Pada praktiknya, petani sering kali menjadi pihak yang dirugikan. Mengapa demikian? Karena pabrik tidak bersedia bertransaksi langsung dengan petani. Hal ini menempatkan posisi tengkulak menjadi sentral dan memiliki akses eksklusif terhadap pabrik. Penjelasan ini merujuk pada pernyataan Husein sebagai berikut:

"Posisina bandol andik akses ka pabrikan, tape posisi paneka bisa abdhina tarema meskipun abdhina rogi, terutama delem tembangan sareng arghe. Bandol ngorangi berre'na tembhengan biasana limak kilo deri berre' se etunnju'aghi neng tembengan se ebitong gebey ongkos transportasi. Jumlah paneka pade sareng arghe duek seket ebu. Ongkos transportasi se sabenynyak ghenika berre' ka abdhina polana 
eterrapaghi ka per bal biasana empat poloh sampa limak poloh kilo bheko. "[Posisi tengkulak memiliki akses ke Pabrikan, namun posisi ini membuat kita terima walaupun harus merugi, terutama dalam timbangan dan harga. Tengkulak mengurangi berat tembakau umumnya lima kilogram dari angka yang ditunjukkan timbangan dan menghitungnya sebagai biaya transportasi. Jumlah ini setara dengan dua ratus lima puluh ribu. Biaya transportasi sebesar ini berat bagi kami karena diterapkan pada tiap bal umumnya empat puluh sampai lima puluh kilogram tembakau.]

Pembebanan seperti itu merupakan kebijakan tengkulak yang tidak bisa dihindari oleh petani. Petani menanggung proses penanaman sampai panen dengan harga panen ditentukan oleh tengkulak. Penentuan harga seperti ini membuat petani sama sekali tidak mempunyai posisi tawar yang cukup dalam menentukan kualitas dan harga tembakau tersebut.

Kualitas dan harga tembakau seperti itu merupakan akumulasi kos yang dikeluarkan selama masa tanam sampai panen. Akumulasi kos ini sebagaimana dinyatakan Ahmad sebagai berikut:

\begin{abstract}
"Arghe se abdhina minta paneka benni arghe se ebey-ghebey, tape arghe ghenika ampon abdhina cocokaghi sareng biaya se abdhina angghuy molae dheri nanem sampe' panen. Paleng bandol paneka tak oning mon abdhina ampon mitong pengeluaran abdhina. Bitongan paneka se dheddi kunci abdhina transaksi sareng bandol. Tape catatan paneka bisa elang mon bandol nentuaghi arghe dhibik se deri pabrik. Mon ampon enga' ghenika, peleanna perak due' engghipaneka ejuel otabe esempen dhibik tape risikona arghe se sajen toron.'[Harga yang kita minta bukan harga yang mengada-ada, namun sudah kami perhitungkan berapa biaya yang sudah saya keluarkan mulai tanam sampai panen. Mungkin tengkulak tidak tahu kalau saya mencatat perhitungan pengeluaran uang. Hitungan ini menjadi kunci saya bertransaksi dengan tengkulak. Namun catatan ini akan hilang ketika tengkulak menetukan harga sendiri disesuaikan dengan pabrik. Kalau sudah seperti ini pilihannya hanya dua yaitu dijual atau ditahan dulu dengan risiko harga yang semakin turun.]
\end{abstract}

Situasi yang dihadapi Ahmad di atas adalah hasil mekanisme pasar lokal terhadap hasil panen tembakau. Mekanisme ini menuntut petani mengeluarkan kos selama proses penanaman, panen, pengolahan, hingga pemasaran. Keseluruhan proses yang membuat beban produksi yang tinggi dan padat modal. Lebih lanjut, petani juga menghadapi keterbatasan alat produksi yang digunakan selama masa tanam tembakau, antara lain traktor, mesin pompa, alat ranjang, dan sak-sak bambu penjemuran.

Pengeluaran seperti itu menambah beban produksi yang ditanggung petani. Oleh karena itu, posisi tawar menjadi lemah dalam menghadapi penentuan harga beli yang ditetapkan tengkulak. Petani adalah ujung mata rantai tata niaga tembakau yang paling tidak diuntungkan, bahkan dapat dikatakan dieksploitasi oleh industri rokok melalui tengkulak.

Kehidupan petani yang paradoksal ini didukung pula oleh berbagai kondisi internal para petani, yang kemudian diperburuk dengan berbagai kondisi eksternal. 
Kondisi internal meliputi keterbatasan lahan yang mereka miliki dan kasus alih tanam karena ingin mencari peluang usaha tani yang lebih menjanjikan, dan keterbatasan pemahaman dalam metode dan teknologi usaha tani yang lebih baik. Kondisi internal ini merupakan kesimpulan pernyataan Kamri sebagai berikut:

"Odikna petani se padena abdhina panika ros-terrosan ebayangi sareng gengguen deri delem dek abdhina se ampon ajelennaghi kalakoan se ampon toronan ben tradisional paneka, ngadebbhi keterbatasan lahan ghebey namen bekoh sareng cuaca se abeobe. Faktor paneka se aghebey abdhina tak bisa ngator biaya se abdhina kaloarraghi."'[Kehidupan petani seperti saya selalu dibayangi oleh gangguan internal atas diri saya sendiri atas usaha turun-temurun dan tradisional, menghadapi keterbatasan lahan untuk menanam tembakau dan cuaca yang tidak menentu. Faktor ini membuat ketidakberdayaan dalam menghitung berapa rupiah yang harus saya keluarkan.]

Pernyataan senada disampaikan oleh Husein adalah:

"Make bekoh paneka benni pole deddhi deun emas, tape ampon deddi usaha toronan se tak elengkapi sareng elmu ben keterampilan kaangghuy ngembangngaghi hasel tanemman se lebih bhegus."[Walaupun tembakau ini bukan lagi daun emas namun sudah menjadi usaha turun-temurun yang tidak dibekali pengetahuan dan keterampilan untuk mengembangkan hasil tanam yang lebih baik. Pola yang sulit dan sampai saat terus berlangsung dengan manis.]

Faktor internal ini mengakibatkan mereka tidak memiliki kemampuan untuk melaksanakan kegiatan budi daya tanaman tembakau secara optimal. Ketidakmampuan ini berakibatkan meningkatnya kos produksi yang dikeluarkan. Sebagaimana hal ini sejalan dengan hasil penelitian Santoso (2011) dan Rokhmah (2014) yang menyatakan bahwa proses perhitungan biaya produksi menjadi masalah pelik bagi petani, karena besar kecilnya keuntungan tembakau menjadi komponen yang dipengaruhi oleh biaya produksi yang membebani mereka.

Biaya produksi tersebut akan berkorelasi dengan keuntungan yang diterima. Ilustrasinya adalah petani mendapatkan keuntungan rata-rata selama satu kali musim tanam sebesar Rp4.061.800,00 (empat juta enam puluh satu ribu delapan ratus rupiah). Jika satu musim rata-rata berlangsung selama empat bulan dengan beban produksi mulai tanam sampai panen sebesar Rp3.050.500,00 (tiga juta lima puluh ribu lima ratus rupiah), maka petani hanya mendapatkan keuntungan sekitar Rp1.000.000,00. Penghasilan ini relatif kecil jika dibandingkan dengan risiko usaha yang ditanggung oleh petani, seperti keterbatasan sarana-prasarana, cuaca, hama dan turunnya harga daun tembakau. Sebagaimana hal ini dinyatakan oleh Ridho sebagai berikut:

"Cuaca paneka e deddhi masalah dek abdhina, polan tanemman bekoh paneka tak bhuto aing benynyak. Abdhina nyiappaghi tempayang paneka ma'le bibit bekoh olle pengairan se cokop, deddi mon etambei ojen paneka bisa mamate tanemman bheko sareng bisa mabede panyake'. Deddi bulen mei paneka bekto namen se bhegus terros panenna paneka bulen agustus sampe' oktober ma'le olle tera'na are ghebey ajemmor bekoh." [Cuaca menjadi hantu bagi saya, karena tanam tembakau hanya membutuhkan air yang sedang. Kalau kita sudah menyiapkan tempayang ini hanya 
untuk bibit tembakau mendapatkan pengairan yang cukup, jadi kalau tambah hujan sama mematikan tumbuhnya tanaman tembakau dan hama. Sehingga bulan mei menjadi masa tanam dan panen jatuh pada Agustus sampai Oktober dengan harapan hasil tembakau mendapatkan cukup cahaya matahari untuk pengeringan.]

Di sisi berikutnya yang bersamaan, petani menghadapi kondisi eksternal yang sangat menekan, yaitu perilaku tengkulak yang secara sepihak menentukan kualitas, timbangan, dan harga tembakau hasil panen serta sebagai produk tanam yang bersifat oligopsoni, sejumlah gudang yang dimiliki sejumlah kecil pabrikan maka dengan mudah mempermainkan "daya tampung" gudang mereka agar petani bersedia menjual hasil panen dengan harga yang semurah-murahnya. Situasi seperti ini membuat "jadwal pembelian" dipermainkan untuk menekan harga tembakau petani.

Sisi internal dan eksternal tersebut menekan harga tembakau. Kondisi ini membuat praktek ekonomi kos produksi tinggi. Tata niaga ini seharusnya lebih memberikan keadilan dan kesejahteraan petani. Walaupun tembakau tidak termasuk sebagai komoditi tani dan pangan strategis, namun komoditi ini merupakan komoditi unggulan di Kabupaten Jember, maka pengaturan penentuan kos produksi sangat diperlukan, terutama untuk tujuan peningkatan dan produktivitas. Perlindungan seperti ini memang seharusnya diterima petani untuk mampu sebagai sarana kebijakan pemberdayaan dan peningkatan kehidupannya.

Upaya untuk mewujudkan hal seperti itu sejalan dengan terbitnya UndangUndang (UU) Nomor 19 Tahun 2013 tentang Perlindungan dan Pemberdayaan Petani. Di samping UU ini juga terdapat sejumlah UU yang memerlukan pengaturan turunan mendukung perlindungan dan pemberdayaan petani tembakau, antara lain UU Nomor 6 Tahun 2014 tentang Desa, UU Nomor 3 Tahun 2014 tentang Perindustrian, UU Nomor 7 Tahun 2014 tentang Perdagangan, UU Nomor 1 Tahun 2013 tentang Lembaga Keuangan Mikro.

Keberadaan UU tersebut memberikan jaminan perlindungan dan pemberdayaan bagi petani yang wajib dilakukan oleh Negara. UU dilatar belakangi oleh keadaan petani yang sering mengalami kerugian, baik akibat kebijakan maupun akibat kondisi alamiah. Lebih lanjut, UU ini memiliki tujuan adalah pertama, mewujudkan kedaulatan dan kemandirian petani dalam rangka meningkatkan taraf kesejahteraan, kualitas, dan kehidupan yang lebih baik. Kedua, menyediakan prasarana dan sarana pertanian yang dibutuhkan dalam mengembangkan usaha tani. Ketiga, memberikan kepastian usaha tani, melindungi petani dari fluktuasi harga, praktik ekonomi biaya tinggi dan gagal panen. Keempat, meningkatkan kemampuan dan kapasitas petani serta kelembagaan petani dalam menjalankan usaha tani produktif, maju, modern dan berkelanjutan. Dan kelima, menumbuhkembangkan kelembagaan pembiayaan pertanian yang mengalami kepentingan usaha tani. 
Keberadaan UU tersebut memberikan jaminan kepada petani dalam menghadapi penetapan harga yang dilakukan oleh tengkulak. Jaminan ini ditegaskan pada UU Nomor 19 Tahun 2013 Pasal 66 yang menyebutkan bahwa Pemerintah dan Pemerintah Daerah sesuai dengan kewenangannya berkewajiban memfasilitasi pembiayaan dan permodalan Usaha Tani. UU ini memang belum sepenuhnya dapat membebaskan petani tembakau dari jeratan tata niaga penetapan harga yang timpang dan posisi tawar yang lemah. Namun bagaimanapun, UU ini menyediakan peluang yang dapat memberikan jalan bagi segala upaya perlindungan dan pemberdayaan petani.

Persoalan penetapan harga daun tembakau secara sepihak oleh tengkulak yang menjadi kaki tangan industri rokok perlu dicarikan solusi. Merujuk hasil wawancara antara Yayuk (tengkulak) dengan para petani sebagai berikut:

Yayuk : Pabrik rokok seng endik modal aberik katentoan arghe dek kule seng tak bisa etaber.[Pabrik rokok selaku pemiliki modal memberikan penentuan harga kepada saya yang tidak mungkin dapat ditawar.]

Husein : Bene metaber tape masokna argeh tak mampo sampek seimbang bik pengeluaran seng bik engkok keluar agi.[Bukan menawar namun masuknya harga belum mampu mencapai seimbangnya pengeluaran yang telah saya keluarkan.]

Yayuk : Engkok gun apatok ke arge seng etetap agi (sambil menunjukkan catatan dari pabrik)...teros engkok apa kodu aberi' tambe'en penetapan arge?[Saya hanya merujuk pada penetapan harga (sambil menunjukkan catatan dari pabrik)...terus saya apakah harus memberikan tambahan penetapan harga?]

Ridho : Kang Husein memantep agi penetapan arge limak atus ebu per gintal padeh beih bik engkok kodu ngetong karenah hasel taneman sampek anyeh ka engkok dibi'. [Kang Husein memantapkan bahwa penentapan harga lima ratus ribu per kuintal sama dengan saya harus menghitung sisanya produksi tanam sampai panen kepada saya sendiri.]

Husein : Ya toreh, tapeh arge seng neng pasaran argene dibebenah haselah engkok. [Ya silahkan, tapi harga yang meluncur itu harga dibawah produksi saya.]

Yayuk : Transaksenah ariah termasok panetapan arge seng eberik pabrek,deddih engkok anetapagin arge riah bik hasel se ementah pabrek.[Transaksi ini merupakan penetapan harga yang diberikan pabrik, jadi saya pun menetapkan harga ini sesuai dengan produk yang diminta pabrik.]

Tengkulak selaku mitra pabrik mengatur penetapan harga seperti dialog di atas merupakan fenomena oligopsoni dan ketidakmampuan petani memasuki pabrik. Hal ini sejalan dengan penelitian yang dilakukan Rokhmah (2014) dan Rachmad (2015) yang menyatakan bahwa penetapan harga tembakau bersifat transaksi spekulatif, artinya motif mencari untung oleh tengkulak lebih dominan karena transaksi tidak diakhiri dengan penyerahan barang, sehingga harga yang terbentuk tanpa memperhatikan kualitas dan petani tidak memiliki daya tawar. Penjelasan ini senada dengan pernyataan Kamri sebagai berikut: 


\begin{abstract}
"Cen ora wis isa maneh ngarepi untung, malah parah saiki regone wes kenemenen njeblok, bakul iku sing ngekeki rego ora isa ditawo maneh. Sek onok pisan sing durung payu.'[Tidak bisa lagi mengharapkan untung, malah semakin parah sekarang harga sudah jatuh berlebihan, penjual itu yang memberi harga tidak bisa ditawar lagi. Bahkan juga masih ada yang belum terjual.]
\end{abstract}

Ketidakmampuan penetapan harga oleh para petani informan tersebut merupakan kajian transaksi tembakau yang tidak melahirkan sistem bayar di akhir oleh tengkulak. Oleh karena itu, solusi yang diberikan dalam penelitian ini, adalah pertama, perlu untuk membantu petani tembakau (dalam hal ini pemerintah Kabupaten Jember) untuk menciptakan mekanisme penentuan harga yang baku dan disepakati oleh kedua belah pihak. Pihak industri rokok harus menjelaskan dengan rinci kualitas daun tembakau yang mempunyai harga mahal kepada para petani, sehingga petani tidak merasa dipermainkan oleh para tengkulak sebagai penentu harga tembakau.

Kedua, untuk melindungi kesejahteraan petani hendaknya dapat ditetapkan harga minimal pembelian daun tembakau. Hal ini dilakukan agar petani tembakau tidak rugi dan mampu menompang hidupnya. Kedua solusi ini menunjukkan kerja sama tripartit antara petani tembakau, industri rokok dan pemerintah Kabupaten Jember (dalam hal ini Dinas Kehutanan dan Perkebunan) dalam pembukaan informasi mengenai kuantitas dan kualitas daun tembakau yang diperlukan industri rokok. Pabrik rokok ini seharusnya terbuka mengenai jumlah persediaan tembakau dan berapa kebutuhan tembakau dengan spesifikasi tertentu sesuai dengan wilayah Jember.

Hal tersebut diperlukan agar Dinas Kehutanan dan Perkebunan (Dithutbun) dan petani mampu membuat perencanaan penentuan pengeluaran-pengeluaran beban produksi, sehingga harga bisa ditentukan dan apabila terjadi penurunan dapat diantisipasi. Selanjutnya, kebijakan secara terbuka mekanisme penentuan harga pabrik dapat diterima petani. Mekanisme ini berjalan apabila pabrik membeli secara langsung kepada petani dan sistem kemitraan. Kemitraan dalam hal ini harmonisasi penentuan kos produksi dari awal masa tanam sampai panen, artinya pabrik dan petani membuka wahana komunikasi intensif dan terbuka beban produksi yang harus dikeluarkan masing-masing.

Harmonisasi kos produksi seperti itu memberikan kepastian usaha dan pemasaran, sehingga petani bukan saja mampu meningkatkan kualitas produksinya, tapi juga memiliki posisi tawar yang lebih kuat dalam penentuan harga daun tembakau. Sudah waktunya cerita paradoks ganda penentuan kos produksi diakhir dan membebaskan petani dari perlakuan semena-mena pihak pabrikan, tengkulak serta kaki tangannya. Di samping para petani bersatu menggalang kekuatan mereka sebagai kekuatan masyarakat sipil, pemerintah sudah selayaknya melaksanakan 
pembaruan menyeluruh terhadap kebijakan dan praktek penentuan kos produksi dengan pendekatan yang lebih pro-petani.

Pada era Masyarakat Ekonomi ASEAN (MEA) maupun era perekonomian global, pemerintah harus berada di pihak petani dan tidak membiarkan Indonesia menjadi pasar produk asing. Kepastian dukungan ini mampu memberikan semangat untuk menciptakan lingkungan yang mendukung terciptanya iklim kondusif bagi perlindungan dan pemberdayaan petani tembakau, sehingga mereka dapat mengakhiri cerita paradoks ganda kos produksi dalam kehidupan mereka.

\section{SIMPULAN, KETERBATASAN DAN SARAN}

"Little evidence indicates that the contents of the many accounting journals are read or noticed by others in the university community. ...more casual, but perhaps more telling, is this question: What big intellectual ideas have accounting researchers contributed to the university? (Fellingham 2007).

Harmonisasi penentuan kos produksi dari awal masa tanam sampai panen merupakan hasil penelitian ini. Harmonisasi kos produksi seperti ini menunjukkan pabrik dan petani membuka wahana komunikasi intensif dan terbuka beban produksi yang harus dikeluarkan masing-masing. Hasil ini diharapkan mengakhir fenomena oligopsoni dan penetapan harga tembakau secara sepihak oleh tengkulak yang menjadi kaki tangan industri rokok. Fenomena ini membuat harga menjadi milik pabrik dan tengkulak, sehingga memberikan posisi tawar yang tinggi dan sebaliknya bagi petani. Di samping itu menumbuhkan ketergantungan sangat tinggi petani kepada pabrik dan atau tengkulak.

Penetapan harga tersebut berkorelasi dengan biaya produksi. Penetapan ini berhubungan dengan keuntungan yang diterima. Oleh karena itu transaksi efektif bukan spekulatif mampu membuat petani melakukan perencanaan penentuan pengeluaran-pengeluaran beban produksi, sehingga harga bisa ditentukan dan apabila terjadi penurunan dapat diantisipasi. Selanjutnya, kebijakan secara terbuka mekanisme penentuan harga pabrik dapat diterima petani. Mekanisme ini berjalan apabila kerja sama tripartit antara petani, pabrik dan pemerintah terjalin harmoni. Sudah waktunya cerita paradoks ganda penentuan kos produksi diakhir.

\section{DAFTAR PUSTAKA}

(IISD), Indonesia Institute for Social Development. 2015. Petani tembakau di Indonesia: sebuah paradoks kehidupan. Yogyakarta: Leutikaprio.

(TCSC)-Indonesia, Tobacco Control Support Center. 2012. Bunga rampai fakta tembakau dan permasalahannya di Indonesia. Jakarta: TCSC-IAKMI.

Basrowi, Muhammad, dan Soenyono. 2004. Teori sosiologi dalam tiga paradigma. Cetakan ke satu. Surabaya: Penerbit Yayasan Kampusina. 
Chamim, Mardiyah. 2011. A giant pack of lies: Bongkah raksasa kebohongan: menyorot kedigdayaan industri rokok di Indonesia. Jakarta: KOJI Communications dan TEMPO Institute.

Fellingham, John C. 2007. "Is accounting an academic discipline?" Accounting Horizons 21 (2): 159-63.

Jayadi, Akhmad, dan Taufik Arbiansyah. 2012. Sengsara di timur Jawa: kisah ketidakberdayaan para petani tembakau Sumenep, Pamekasan dan Jember menghadapi tata niaga tembakau yang memiskinkan. Jakarta: Yayasan Indonesia Sehat.

Keyser, John C, dan Nila Ratna Juita. 2005. "Smallholder tobacco growing in Indonesia: cost and profitability compared agricultural enterprises." Jakarta.

Kuswarno, Engkus. 2009. Metodologi penelitian komunikasi fenomenologi: Konsepsi, pedoman, dan contoh penelitiannya. Bandung: Penerbit Widya Padjadjaran.

Mastur. 2014. "Penelitian tanaman tembakau dan diversifikasi produknya." Universitas Muhammadiyah Jakarta.

Rachmad, M. 2015. "Mengerdilkan tembakau: Petani tembakau belum menjadi prioritas. Edisi 30, XXVI." Majalah Mahasiswa Fakultas Ekonomi (ECPOSE) Universitas Jember, 2015.

Rokhmah, Dewi. 2014. "Analisis faktor risiko green tobacco sickness (GTS) dan metode penanganannya pada petani tembakau," 1-14.

Saliem, H.P. 2014. "Permasalahan dan tantangan pertanian tembakau serta solusinya."

Samryn, L.M. 2013. Akuntansi manajemen informasi biaya untuk mengendalikan aktivitas operasi dan investasi. Edisi revisi. Jakarta: Penerbit Kencana Prenadamedia Group.

Santoso, T. 2011. "Tata niaga tembakau di Madura." Jurnal Manajemen dan Kewirausahaan 3 (2): 7-19.

SEATCA. 2008. Cycle of poverty in tobacco farming: tobacco cultivation in Southeast Asia. Bangkok: SEATCA.

Sugiri, Slamet. 2009. Akuntansi managemen sebuah pengantar. Edisi ke empat. Yogyakarta: Penerbit UPP STIM YKPN.

Suwardjono. 2016. Akuntansi pengantar bagian 1 proses penciptaan data pendekatan sistem. Cetakan ke tujuh. Yogyakarta: BPFE.

The, Ishak, dan Arief Sugiono. 2015. Akuntansi informasi dalam pengambilan keputusan. Cetakan ke satu. Jakarta: Penerbit PT.Grasindo. 